Original Research Article

\title{
Antiangiogenic activity of zinc and zinc-sorafenib combination using the chick chorioallantoic membrane assay: a descriptive study
}

\author{
Manu Kumar ${ }^{1}$, Girish Gulab Meshram ${ }^{2 *}$, Tripti Rastogi ${ }^{1}$, Sonal Sharma ${ }^{3}$, Rachna Gupta ${ }^{1}$, \\ Seema Jain $^{1}$, Anisha Prasad ${ }^{1}$, Vikas Galav ${ }^{4}$, S. K. Bhattacharya ${ }^{1}$
}

\begin{abstract}
${ }^{1}$ Department of Pharmacology, University College of Medical Sciences and Guru Teg Bahadur Hospital, New Delhi, India ${ }^{2}$ Department of Pharmacology, Postgraduate Institute of Medical Education and Research and Dr. Ram Manohar Lohia Hospital, New Delhi, India ${ }^{3}$ Department of Pathology, ${ }^{4}$ Central Animal House, University College of Medical Sciences and Guru Teg Bahadur Hospital, New Delhi, India
\end{abstract}

Received: 04 April 2017 Accepted: 08 April 2017

*Correspondence to: Dr. Girish Gulab Meshram, Email: drgirish23@yahoo.co.in

Copyright: (C) the author(s), publisher and licensee Medip Academy. This is an openaccess article distributed under the terms of the Creative Commons Attribution NonCommercial License, which permits unrestricted noncommercial use, distribution, and reproduction in any medium, provided the original work is properly cited.

\begin{abstract}
Background: Zinc, a trace element, is known for downregulating several proangiogenic growth factors and cytokines. However, its antiangiogenic activity is not adequately studied. The present study was aimed to evaluate the possible antiangiogenic activity of zinc via the chick chorioallantoic membrane (CAM) assay. Also, the antiangiogenic activity of the combination therapy of zinc with various doses of sorafenib, a tyrosine kinase inhibitor, was evaluated. Methods: A pilot study was initially conducted so as to select suitable doses of zinc and sorafenib. The antiangiogenic activity after combining zinc 2.5 $\mu \mathrm{g} /$ embryo with sorafenib 1 , and $2 \mu \mathrm{g} /$ embryo was also evaluated. The antiangiogenic activity was quantified in terms of total length of blood vessels, number of junctions, number of branching points, and mean length of the blood vessels.

Results: Zinc $2.5 \mu \mathrm{g} /$ embryo showed significant $(\mathrm{p}<0.05)$ antiangiogenic activity, as compared to the control group. However, its effect was not comparable to that of sorafenib $2 \mu \mathrm{g} /$ embryo. The combination of zinc 2.5 $\mu \mathrm{g} /$ embryo with sorafenib $2 \mu \mathrm{g}$ /embryo did not show an additive/synergistic effect. The combination of zinc $2.5 \mu \mathrm{g}$ /embryo with sorafenib $1 \mu \mathrm{g} / \mathrm{embryo}$ produced an antiangiogenic activity which was comparable $(p>0.05)$ to that of sorafenib $2 \mu \mathrm{g}$ /embryo.

Conclusions: Zinc caused significant antiangiogenic activity in the CAM assay. The lack of addition/synergism in the zinc-sorafenib combination could have been due to the variability in the dose/ratio selection. Addition of zinc to sorafenib therapy could improve treatment tolerability, reduce cost of therapy, and reduce the emergence of drug resistance. Future mechanistic studies could identify the exact pharmacodynamics of zinc as an angiogenesis inhibitor.
\end{abstract}

Keywords: Aantiangiogenic, Chick chorioallantoic membrane assay, Sorafenib, Zinc

\section{INTRODUCTION}

Angiogenesis, the formation of new blood vessels from pre-existing ones, is critical for the progression and metastasis of several solid vascular tumours such as renal cell, hepatocellular, and colorectal cancers. ${ }^{1}$ The angiogenesis inhibitors approved for cancers include bevacizumab, sunitinib, and sorafenib. Bevacizumab blocks the vascular endothelial growth factor (VEGF), one of the major growth factors for angiogenesis. Sunitinib, and sorafenib inhibit the enzyme tyrosine kinase, which regulates several proangiogenic growth factor receptors. ${ }^{2}$ However, the clinical benefits of these agents have been limited to only an increase in the progression-free survival. ${ }^{3}$ Also, due to an increase in the emergence of resistance to these agents, there is an 
enormous interest in researchers to develop novel angiogenesis inhibitors with efficient therapeutics. ${ }^{4}$

Despite a large body of evidence pointing towards the antiangiogenic activity of zinc, the potential of zinc, as an angiogenesis inhibitor, remains unexplored. First, depletion of zinc has been reported to increase the expression of proangiogenic cytokines such as VEGF, interleukin 6 (IL-6), and IL-8 in prostate cancer cells. ${ }^{5}$ Second, zinc reduced the expression of hypoxia-inducible factor 1- $\alpha$ (HIF-1 $\alpha$ ), the master transcription factor for hypoxia-induced angiogenesis, in tumour cells. ${ }^{6}$ Third, zinc also increases the expression of p53 in tumour cells leading to reduced expression of VEGF. ${ }^{7}$ Fourth, zinc also reduces the levels of homeodomain-interacting protein kinase-2 (HIPK-2) and glycogen synthase kinase$3 \beta$ (GSK-3 $\beta)$, both players in the process of angiogenesis. ${ }^{8,9}$ With this backdrop in mind, the present study was aimed to evaluate the possible antiangiogenic activity of zinc using the chick chorioallantoic membrane (CAM) assay. The possibility of an additive effect after combining zinc with various doses of sorafenib, an approved angiogenesis inhibitor, was also evaluated.

\section{METHODS}

\section{Drugs}

Pure zinc powder was purchased from Merck Ltd., Mumbai, India and sorafenib was purchased from SigmaAldrich, St. Louis, MO, USA.

\section{Chick chorioallantoic membrane (CAM) assay}

Fresh fertilized chicken eggs of the Lohmann Brown variety were purchased from Keggfarms, Gurgaon, India, and disinfected with $70 \%$ ethanol. The eggs were then placed in an incubator (United National Scientific Co., Kolkata, India) at $37^{\circ} \mathrm{C}$ and $65 \%$ relative humidity for embryogenesis. On the third day of incubation, a tiny window was made on the apex of each of the eggs and the eggs were sealed with paraffin film (American Can Co., Greenwich, CT, USA) to avoid contamination of the egg contents. On the fifth day of incubation, the windows on the eggs were reopened and the test/control drugs were applied on the developing CAMs before resealing the eggs. On the fourteenth day of incubation, the CAMs were separated for quantifying the angiogenesis (Figure 1). ${ }^{10}$

\section{Quantification of angiogenesis}

The CAMS were photographed (Model ProgRes C5, Jenoptic Inc., Jena, Germany) using the magnification of 4X. After indentifying and specifying the regions of interest in the images, the images were optimized, thresholded, and skeletonised so as to calculate the 1) Total length 2) Number of junctions 3) Number of branches 4) Mean branch length of the blood vessels, using the software Angiosys version 2.0 (Cellworks, Caltag Medsystems Ltd., Buckingham, UK) (Figure 2). ${ }^{11}$

\section{Doses of zinc and sorafenib}

For determining suitable doses of zinc and sorafenib, a pilot study was initially conducted by administering zinc in doses of $2.5,5,10$, and $20 \mu \mathrm{g} /$ embryo and sorafenib in doses of 2 , and $3 \mu \mathrm{g} /$ embryo to the CAMs ( $\mathrm{n}=6$ in each group). ${ }^{12,13}$ Normal saline was used as the control. Subsequently, the doses of zinc and sorafenib showing maximal efficacy in the CAM assay, amongst the doses evaluated, were combined together so as to observe the effect of the combination therapy. Subsequently, a lower dose of sorafenib i.e. $1 \mu \mathrm{g}$ /embryo was combined with the most efficacious dose of zinc to evaluate their combined efficacy.

\section{Statistical analysis}

Results are expressed as mean \pm standard error of mean (SEM). Statistical analysis was performed using one-way analysis of variance (ANOVA) followed by multiple Tukey's comparison test. A value of $p<0.05$ was considered statistically significant.

Two-way multivariate ANOVA (MANOVA) was utilized to compare the main effect of sorafenib and zinc and the interaction effect between sorafenib and zinc on the total length, branches, junctions, and mean branch length of blood vessels. For the two-way MANOVA, sorafenib included 2 levels ( 0 , and $2 \mu \mathrm{g} /$ embryo) and zinc contained 2 levels ( 0 , and $2.5 \mu \mathrm{g} / \mathrm{embryo})$.

\section{RESULTS}

Zinc in the dose of $2.5 \mu \mathrm{g} / \mathrm{embryo}$ showed significant ( $\mathrm{p}$ $<0.05$ ) antiangiogenic activity, as compared to the control group. Since two of the CAMs in the zinc $5 \mu \mathrm{g} / \mathrm{embryo}$ group did not show any embryogenesis, the effect of the zinc $5 \mu \mathrm{g} /$ embryo group could not be compared to that of the zinc $2.5 \mu \mathrm{g} / \mathrm{embryo}$ group. The 10 and $20 \mu \mathrm{g} / \mathrm{embryo}$ doses of zinc showed toxic effects leading to no embryogenesis in all of the CAMs (Figure 1). Sorafenib 2 , and $3 \mu \mathrm{g} /$ embryo showed significant ( $\mathrm{p}<0.05$ ) antiangiogenic activity, as compared to the control group (Table 1). However, sorafenib $2 \mu \mathrm{g} / \mathrm{embryo}$ was chosen as the reference standard owing to a lower risk of toxicity to the CAMs. The antiangiogenic activity of zinc 2.5 $\mu \mathrm{g} /$ embryo was significantly $(\mathrm{p}<0.05)$ lower than that of sorafenib $2 \mu \mathrm{g} / \mathrm{embryo}$. The results of the pilot study indicated zinc $2.5 \mu \mathrm{g} /$ embryo and sorafenib $2 \mu \mathrm{g} /$ embryo as efficacious and non-toxic doses, hence, were selected for the subsequent part of the study (Figure 2, Figure 3, Table 1).

The combination of zinc $2.5 \mu \mathrm{g}$ /embryo with sorafenib 2 $\mu \mathrm{g} /$ embryo showed significant $(\mathrm{p}<0.05)$ antiangiogenic activity, as compared to the control group. However, its effect was not significantly $(\mathrm{p}<0.05)$ superior to that of 
sorafenib $2 \mu \mathrm{g} / \mathrm{embryo}$. Zinc $2.5 \mu \mathrm{g} /$ embryo combined with sorafenib $1 \mu \mathrm{g} / \mathrm{embryo}$ showed significant $(\mathrm{p}<0.05)$ antiangiogenic activity, as compared to the control group.
Also, this combination did not show a significant ( $\mathrm{p}$ $<0.05)$ difference from the antiangiogenic activity of the sorafenib $2 \mu \mathrm{g} / \mathrm{embryo}$ group (Table 1).

Table 1: Antiangiogenic activity of zinc, sorafenib, and their combinations in the chick chorioallantoic membrane (CAM) assay.

\begin{tabular}{|c|c|c|c|c|}
\hline Group/Parameter & Total length (pixels) & Junctions (n) & Branches (n) & $\begin{array}{l}\text { Mean branch length } \\
\text { (pixels) }\end{array}$ \\
\hline Control $(n=6)$ & $150230 \pm 4378$ & $10232 \pm 302$ & $9202 \pm 349$ & $19.33 \pm 0.99$ \\
\hline Zinc $2.5 \mu \mathrm{g} /$ embryo $(\mathrm{n}=6)$ & $105298 \pm 3518^{\mathrm{a}, \mathrm{b}}$ & $7340 \pm 120^{\mathrm{a}, \mathrm{b}}$ & $6672 \pm 108^{\mathrm{a}, \mathrm{b}}$ & $17.17 \pm 0.54$ \\
\hline Zinc $5 \mu$ g/embroyo $(n=4)$ & $83094 \pm 6276$ & $6742 \pm 153$ & $5983 \pm 94$ & $17.00 \pm 0.91$ \\
\hline Zinc $10 \mu \mathrm{g} /$ embroyo $(\mathrm{n}=0)$ & - & - & - & - \\
\hline Zinc $20 \mu \mathrm{g} / \mathrm{embroyo}(\mathrm{n}=0)$ & - & - & - & - \\
\hline Sorafenib $2 \mu \mathrm{g}$ /embryo $(\mathrm{n}=6)$ & $69037 \pm 1594^{\mathrm{a}}$ & $4769 \pm 159^{a}$ & $4306 \pm 143^{\mathrm{a}}$ & $16.67 \pm 0.49^{a}$ \\
\hline Sorafenib $3 \mu \mathrm{g} /$ embryo $(n=6)$ & $57766 \pm 1681^{\mathrm{a}}$ & $3773 \pm 218^{\mathrm{a}, \mathrm{b}}$ & $3425 \pm 138^{\mathrm{a}, \mathrm{b}}$ & $15.83 \pm 0.70^{\mathrm{a}}$ \\
\hline $\begin{array}{l}\text { Zinc } 2.5 \mu \mathrm{g} / \text { embryo }+ \\
\text { Sorafeinib } 2 \mu \mathrm{g} / \text { embryo }(\mathrm{n}=6)\end{array}$ & $62704 \pm 1497^{a}$ & $4412 \pm 162^{\mathrm{a}}$ & $3908 \pm 117^{\mathrm{a}}$ & $16.00 \pm 0.52^{\mathrm{a}}$ \\
\hline $\begin{array}{l}\text { Zinc } 2.5 \mu \mathrm{g} / \mathrm{embryo}+ \\
\text { Sorafenib } 1 \mu \mathrm{g} / \mathrm{embryo}(\mathrm{n}=6)\end{array}$ & $79862 \pm 1951^{\mathrm{a}}$ & $5319 \pm 198^{a}$ & $4826 \pm 205^{\mathrm{a}}$ & $16.67 \pm 0.42^{\mathrm{a}}$ \\
\hline
\end{tabular}

One-way ANOVA followed by multiple Tukey's comparison test. Values are the mean \pm SEM. ${ }^{\text {a }}$ Indicates $p<0.05$, as compared to the control group. ${ }^{\mathrm{b}}$ Indicates $p<0.05$, as compared to the sorafenib $2 \mu \mathrm{g} / \mathrm{embryo}$ group.
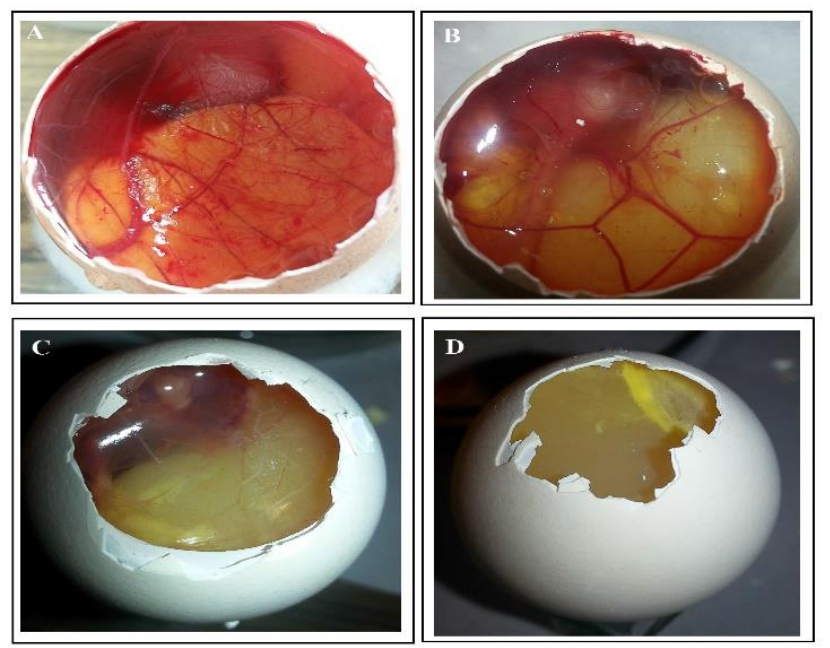

Figure 1: Photographs of the pilot study showing a fourteenth day fertilized egg subjected to normal saline (A), zinc $2.5 \mu \mathrm{g} / \mathrm{embryo}(\mathrm{B})$, sorafenib 2 $\mu \mathrm{g} / \mathrm{embryo}(\mathrm{C})$, and zinc $10 \mu \mathrm{g} / \mathrm{embryo}(\mathrm{D})$.

Zinc $2.5 \mu \mathrm{g} / \mathrm{embryo}$ significantly $(\mathrm{p}<0.05)$ reduced three of the parameters observed for quantifying angiogenesis i.e. total length of the blood vessels, number of branching points, and number of junctions, but not the mean branch length ( $p=0.89)$ of the blood vessels, as compared to the control group. Sorafenib and both the combination therapy groups significantly $(\mathrm{p}<0.05)$ reduced all the four abovementioned quantification parameters, as compared to the control group (Table 1, Figure 2). Following twoway MANOVA, the main effect for sorafenib yielded $\mathrm{F}$ ratios of $F(1,20)=421.79, F(1,20)=347.93, F(1,20)=$ 445.64 , and $\mathrm{F}(1,20)=8.24$ for total length, branches, junctions, and mean branch length, respectively, with $\mathrm{p}$ $<0.05$, indicating a significant difference between sorafenib $0 \mu \mathrm{g} / \mathrm{embryo}$ and sorafenib $2 \mu \mathrm{g} / \mathrm{embryo.}$
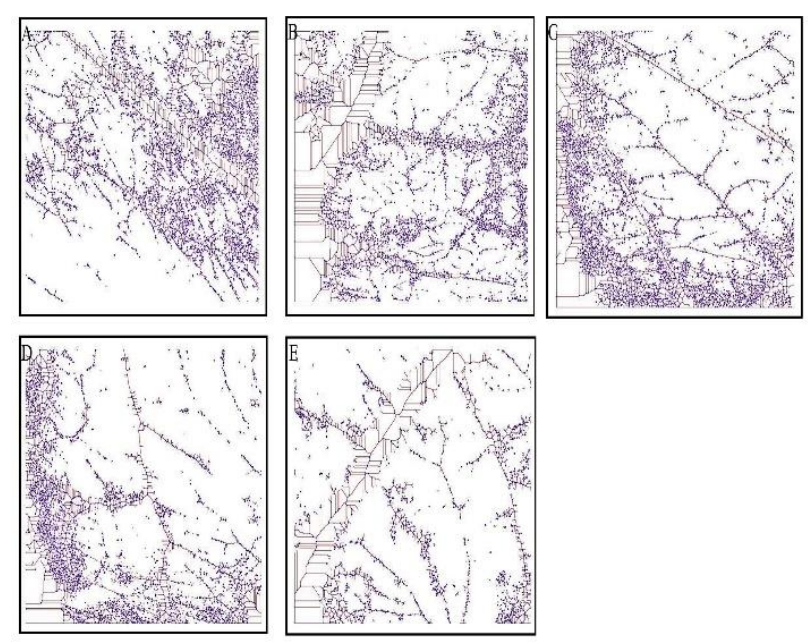

Figure 2: Final processed images by Angiosys 2.0 showing angiogenesis in the chick chorioallantoic membranes subjected to normal saline (A), zinc 2.5 $\mu \mathrm{g} /$ embryo (B), sorafenib $2 \mu \mathrm{g} /$ embryo (C), zinc 2.5 $\mu \mathrm{g} / \mathrm{embryo}+$ sorafenib $2 \mu \mathrm{g} / \mathrm{embryo}(\mathrm{D})$, and zinc 2.5 $\mu \mathrm{g} / \mathrm{embryo}+$ sorafenib $1 \mu \mathrm{g} / \mathrm{embryo}$.

The main effect for zinc yielded $\mathrm{F}$ ratios of $\mathrm{F}(1,20)=$ $72.34, \mathrm{~F}(1,20)=50.81, \mathrm{~F}(1,20)=66.81$, and $\mathrm{F}(1,20)=$ 4.50 for total length, branches, junctions, and mean branch length, respectively, with $\mathrm{p}<0.05$, indicating that the effect was significantly different between zinc 0 $\mu \mathrm{g} / \mathrm{embryo}$ and zinc $2.5 \mu \mathrm{g}$ /embryo. There was a 
statistically significant interaction between sorafenib and zinc on total length $(\mathrm{F}(1,20)=41.01, \mathrm{p}<0.05)$, branches $(\mathrm{F}(1,20)=26.98, \mathrm{p}<0.05)$, and junctions $(\mathrm{F}(1,20)=$ $40.71, \mathrm{p}<0.05)$ but not on the mean branch length ( $\mathrm{F}(1$, $20)=1.26, p=0.28)$. The interaction effect between sorafenib and zinc on each of the dependent variables is depicted graphically (Figure 4).

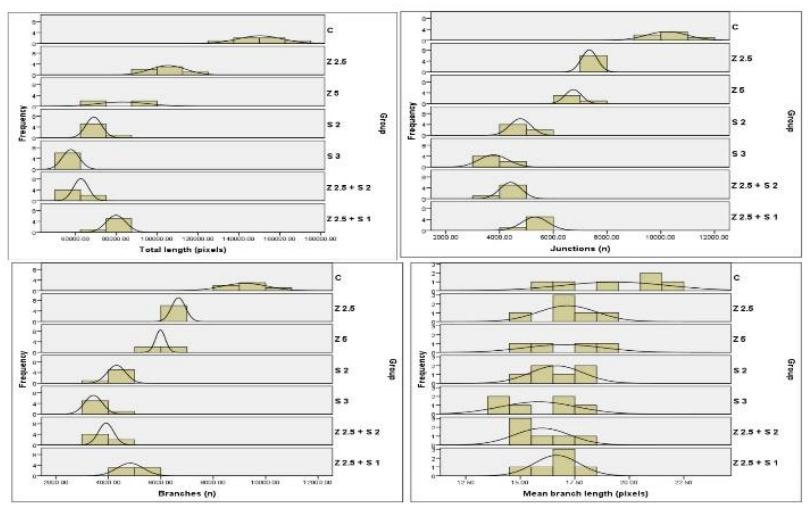

C, control; Z 2.5, zinc $2.5 \mu \mathrm{g} /$ embryo; Z 5, zinc $5 \mu \mathrm{g} /$ embryo; S 1 , sorafenib $1 \mu \mathrm{g}$ /embryo; S 2, sorafenib $2 \mu \mathrm{g}$ /embryo; S 3, sorafenib $3 \mu \mathrm{g} / \mathrm{embryo}$

Figure 3: Histograms showing the antiangiogenic activity of zinc, sorafenib, and their combinations in the chick chorioallantoic membrane assay.

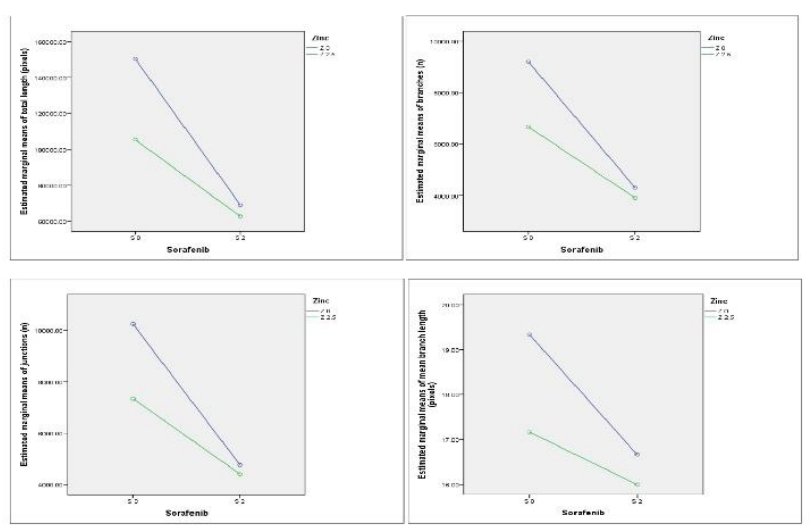

S 0 , sorafenib $0 \mu \mathrm{g}$ /embryo; S 2, sorafenib $2 \mu \mathrm{g}$ /embryo; Z 0 , zinc $0 \mu \mathrm{g} /$ embryo; $\mathrm{Z} 2.5$, zinc $2.5 \mu \mathrm{g} / \mathrm{embryo}$

Figure 4: Parallel lines indicate no interaction effect. Converging lines indicate a positive interaction effect. Diverging lines indicate a negative interaction effect.

\section{DISCUSSION}

In recent years, numerous reports have focused on the anticancer activity of zinc. However, no study so far has evaluated the antiangiogenic activity of zinc in the CAM assay. In the present study, zinc was found to be effective in inhibiting angiogenesis in the CAM assay. Also, the combination of zinc with a lower dose of sorafenib i.e.1 $\mu \mathrm{g} / \mathrm{embryo}$ was found to be as effective as a higher dose of sorafenib i.e. $2 \mu \mathrm{g} /$ embryo in inhibiting angiogenesis. These findings will carve the way for future studies, evaluating the role of zinc in angiogenesis.
The CAM assay is a classic model for screening novel antiangiogenic agents. It provides a natural in-vivo environment for angiogenesis with an advantage of direct application of test compounds to the membrane, the effect of which can be visualized and quantified in real time. ${ }^{10}$

To ensure appropriate doses of zinc and sorafenib, in the present study, a pilot study was initially conducted. For the pilot study, the doses of zinc $2.5,5,10$, and 20 $\mu \mathrm{g} /$ embryo and sorafenib 2 , and $3 \mu \mathrm{g} /$ embryo were selected on the basis of previous studies. ${ }^{12,13}$

Zinc has shown to have a conflicting role in the process of angiogenesis. On one hand, zinc fingers, zinc sulphate, and zinc oxide nanoparticles have been reported to promote angiogenesis by upregulating proangiogenic factors such as VEGF, and fibroblast growth factor (FGF) and downregulating matrix metalloproteinases, while on the other hand, zinc has also been reported to reduce proangiogenic factors such as VEGF, IL-2, IL-6, IL-8, HIF-1 $\alpha$, HIPK-2, and GSK-3 $\beta$ and increase the expression of $\mathrm{p} 53$, an antiangiogenic factor, in previous reports. ${ }^{5-9,14-18}$ Zinc also inhibits inhibitor of $\kappa$ B kinase (I $\mathrm{B}$ kinase) which results in nuclear factor $\kappa \mathrm{B}(\mathrm{NF}-\kappa \mathrm{B})$ inhibition downstream of the mitogen-activated protein kinase (MAPK) pathway leading to reduced angiogenesis. ${ }^{19}$ Also, the binding of zinc to endostatin, a potent angiogenesis inhibitor, is essential for the antiangiogenic activity of endostatin. ${ }^{20}$ The overall action of zinc appears to be antiangiogenic, as found in the present study, which is in alignment with the results of previous studies. $^{21,22}$ The differential effect of zinc on angiogenesis could be dependent on the particle size, particle surface chemistry, dose-dilution, cell type, and mode of delivery. Sorafenib, an approved angiogenesis inhibitor, acts by inhibiting the enzyme tyrosine kinase, responsible for the activation of VEGF and PGDF receptors. $^{2}$

The use of angiogenesis inhibitors in cancer therapy has resulted in moderate improvement in survival rates along with considerable adverse effects. ${ }^{1}$ The major roadblocks identified for their limited success include patient/tumour heterogeneity, limited dose schedules due to drug toxicity, and emergence of drug resistance. ${ }^{3}$ To tackle the tangible hurdles of drug resistance and drug toxicity, a combination of two different angiogenesis inhibitors acting via diverse mechanisms, or a combination of one angiogenesis inhibitor with one low-dose anticancer agent is often sought. ${ }^{4}$ Zinc could be an excellent option for such a combination therapy due to its dual action of inhibiting both angiogenesis, and tumour cell growth and also due to its involvement in several angiostatic signalling pathways. However, in the present study, the combination of zinc $2.5 \mu \mathrm{g} /$ embryo with sorafenib 2 $\mu \mathrm{g} /$ embryo, showed only a marginal improvement in the antiangiogenic activity, as compared to sorafenib 2 $\mu \mathrm{g} / \mathrm{embryo}$ monotherapy, making the interaction effect partially enhancing in nature. The lack of synergism or 
additive effect between sorafenib and zinc could be explained by the fact that the phenomena of synergism and addition between two angiostatic agents are dose/ratio dependent. A small change in the dose/ratio of even one of the agents may lead to loss of synergism/addition. ${ }^{3,23}$ Also, in anticancer therapy, the sequence of administering two agents can influence the efficacy of the combination therapy. ${ }^{24}$ The presence of a drug-drug interaction between sorafenib and zinc, partially buffering the overall antiangiogenic activity of the zinc-sorafenib combination, cannot be ruled out either. When a lower dose of sorafenib i.e. $1 \mu \mathrm{g} /$ embryo was combined with zinc $2.5 \mu \mathrm{g} / \mathrm{embryo}$, the effect was comparable to that of sorafenib $2 \mu \mathrm{g} / \mathrm{embryo}$ monotherapy. Hence, combining zinc with sorafenib could lower the dose of sorafenib, making the treatment more tolerable and cost-effective. Furthermore, GSK-3 activity induced by sorafenib in cancer cells is one of the potential causes for its resistance. ${ }^{25}$ Zinc inhibits GSK-3 and could be an effective option as a combination agent with sorafenib. However, more in-depth studies are warranted to ascertain these findings.

The present study has numerous limitations. First, the doses of zinc and sorafenib were not calculated by $\mathrm{LD}_{50}$ estimation by dose-dependent toxicity studies, keeping in mind the narrow therapeutic window of metallic ions in therapeutics. ${ }^{14}$ Second, although zinc showed significant antiangiogenic activity in the CAM assay, due to the absence of mechanistic studies, measuring levels of proangiogenic and antiangiogenic factors affected by zinc, the exact pharmacodynamics of zinc, as an antiangiogenic agent, remains yet unexplained. Third, only one model i.e. the CAM assay was employed to measure the antiangiogenic activity of zinc. Fourth, although there was a significant interaction effect found between zinc and sorafenib in 3 of the dependent variables, pharmacokinetic/molecular/isobolographic studies, evaluating the nature and molecular mechanism underlying this interaction effect were not conducted. Future studies employing a combination of assays for accurate identification of the cellular and molecular events in angiogenesis targeted by zinc and could give a complete picture of its antiangiogenic potential. Future isobolographic studies could identify the exact nature of the interaction between zinc and sorafenib.

\section{CONCLUSION}

In conclusion, the study shows that zinc effectively inhibits angiogenesis in the CAM assay. The mechanism postulated for its antiangiogenic action includes inhibition of multiple proangiogenic growth factors and cytokines. The combination of zinc with other angiogenesis inhibitors, including sorafenib, could provide an excellent opportunity for improving angiostatic therapy by reducing the incidence of drug resistance, reducing cost of therapy, and improving treatment tolerability in patients. Future mechanistic studies could shed light on the exact pharmacodynamics and role of zinc in angiogenesis for its successful translation to the clinic, as an effective angiogenesis inhibitor.

\section{ACKNOWLEDGEMENTS}

The corresponding author presented the study as an oral presentation at the 50th Annual Inaugural Golden Jubilee Conference of the Indian Pharmacological Society.

\section{Funding: No funding sources}

Conflict of interest: None declared

Ethical approval: The study was approved by the Institutional Animal Ethics Committee of UCMS and GTBH

\section{REFERENCES}

1. Vasudev NS, Reynolds AR. Anti-angiogenic therapy for cancer: current progress, unresolved questions and future directions. Angiogenesis 2014;17:471-94.

2. Chabner BA, Barnes J, Neal J, Olson E, Mujagic H, Sequist L, et al. Targeted therapies: tyrosine kinase inhibitors, monoclonal antibodies, and cytokines. In: Brunton LL (ed). Goodman and Gillman's The Pharmacolological Basis of Therapeutics. 12th ed. New York, NY: McGraw-Hill. 2011:1731-53.

3. Ebos JM, Kerbel RS. Antiangiogenic therapy: impact on invasion, disease progression, and metastasis. Nat Rev Clin Oncol. 2011;8:210-21.

4. van Beijnum JR, Nowak-Sliwinska P, Huijbers EJ, Thijssen VL, Griffioen AW. The great escape; the hallmarks of resistance to antiangiogenic therapy. Pharmacol Rev. 2015;67:441-61.

5. Golovine K, Uzzo RG, Makhov P, Crispen PL, Kundle D, Kolenko M. Depletion of intracellular zinc increases expression of tumorigenic cytokines VEGF, IL-6, IL-8 in prostate cancer cells via NF-kappaBdependent pathway. Prostate. 2008;68:1443-9.

6. Nardinocchi L, Pantisano V, Puca R, Porru M, Aiello A, Grasselli A, et al. Zinc downregulates HIF-1 $\alpha$ and inhibits its activity in tumor cells In Vitro and In Vivo. PLos One. 2010;5:15048.

7. Dhawan DK, Chadha VD. Zinc: a promising agent in dietary chemoprevention of cancer. Indian $\mathbf{J}$ Med Res. 2010;132:676-82.

8. Margalit O, Simon AJ, Yakubov E, Puca R, Yosepovich A, Avivi C, et al. Zinc supplementation augments in vivo antitumor effect of chemotherapy by restoring p53 function. Int $\mathrm{J}$ Cancer. 2011;131:562-8.

9. Ilouz R, Kaidanovich O, Gurwitz D, Eldar-Finkelman H. Inhibition of glycogen synthase kinase-3beta by bivalent zinc ions: insight to the insulin-mimetic action of zinc. Biochem Biophys Res Commun. 2002;295:102-6.

10. Ribatti D, Vacca A, Roncali L, Dammacco F. The chick chorioallantoic membrane as a model for in vivo research on anti-angiogenesis. Curr Pharm Biotechnol. 2000;1:73-82. 
11. Khoo CP, Micklem K, Watt SM. A comparison of methods for quantifying angiogenesis in the matrigel assay In Vitro. Tissue Eng Part C Methods. 2011;17:895-906.

12. Uzzo RG, Crispen PL, Golovine K, Makhov $\mathrm{P}$, Horwitz EM, Kolenko VM. Diverse effects of zinc on NF-kappaB and AP-1 transcription factors: implications for prostrate progression. Carcinogenesis. 2006;27:1980-90.

13. Nowak-Sliwinska $P$, Weiss A, van Beijnum JR, Wong TJ, Ballini JP, Lovisa B, et al. Angiostatic kinase inhibitors to sustain photodynamic angioocclusion. J Cell Mol Med. 2012;16:1553-62.

14. Bozym RA, Chimienti F, Giblin LJ, Gross GW, Korichneva I, Li Y, et al. Free zinc outside a narrow concentration range are toxic to a variety of cells in vitro. Exp Biol Med (Maywood). 2010;235:742-50.

15. Barui AK, Veeriah V, Mukherjee S, Manna J, Patel AK, Patra S, et al. Zinc oxide nanoflowers make new blood vessels. Nanoscale. 2012;4:7861-9.

16. Kaji T, Fujiwara Y, Yamamoto C, Sakamoto M, Kozuka H. Stimulation by zinc of cultured vascular endothelial cell proliferation: possible involvement of endogenous basic fibroblast growth factor. Life Sci 1994;55:1781-7.

17. Pasqualini R, Barbas CF 3rd, Arap W. Vessel maneuvers: zinc fingers promote angiogenesis. Nat Med. 2002;8:1353-4.

18. Prasad AS. Effects of zinc deficiency on Th1 and Th2 cytokine shifts. J Infect Dis. 2000;183:62-8.

19. Saghri MA, Astaourian A, Orangi J, Sorenson CM, Sheibani N. Functional role of inorganic trace elements in angiogenesis-Part II: $\mathrm{Cr}, \mathrm{Si}, \mathrm{Zn}, \mathrm{Cu}$, and S. Crit Rev Oncol Hematol. 2015;96:143-55.
20. Boehm T, O'reilly MS, Keough K, Shiloach J, Shapiro R, Folkman J. Zinc binding of endostatin is essential for its antiangiogenic activity. Biochem Biophys Res Commun. 1998;252:190-4.

21. Nishida N, Yano H, Nishida T, Kamura T, Kojiro M. Angiogenesis in cancer. Vasc Health Risk Manag. 2006;2:213-9.

22. Tada-Oikawa S, Ichihara G, Suzuki Y, Izuoka K, Wu $\mathrm{W}$, Yamada Y, et al. Zn (II) released from zinc oxide nano/micro particles suppresses vasculogenesis in human endothelial colony-forming cells. Toxicology Reports. 2015;2:692-701.

23. Osterhoudt KC, Penning TM. Drug toxicity and poisoning. In: Brunton LL (ed). Goodman and Gillman's The Pharmacolological Basis of Therapeutics. $12^{\text {th }}$ ed. New York, NY: McGraw-Hill; 2011:73-87.

24. Albiges L, Choueiri T, Escudier B, Gaisky M, George D, Hofmann F, et al. A systematic review of sequencing and combination of systemic therapy in metastatic renal cancer. Eur Urol. 2015;67:100-10.

25. Kawazoe H, Bilim VN, Ugolkov AV, Yuuki K, Naito S, Nagaoka A, et al. GSK-3 inhibition in vitro and in vivo enhances antitumor effect of sorafenib in renal cell carcninoma (RCC). Biochem Biophys Res Commun. 2012;423:490-5.

Cite this article as: Kumar M, Meshram GG, Rastogi T, Sharma S, Gupta R, Jain S, et al. Antiangiogenic activity of zinc and zinc-sorafenib combination using the chick chorioallantoic membrane assay: a descriptive study. Int J Basic Clin Pharmacol 2017;6:1060-5. 